\title{
The Multiple Discrimination in the European and Italian Context
}

\section{Definition}

The term "multiple discrimination" indicates any combination of discrimination on the grounds of gender, racial or ethnic origin, religion or belief, disability, age or sexual orientation.

The concept of multiple discrimination has been pioneered in the 80 s in the US by an American scholar, Kimberlé Crenshaw, in order to identify new forms of discrimination. Crenshaw called attention to the many ways in which race and gender interacted to shape experiences of black women. The argument put forward was that individuals can belong to several disadvantaged groups and potentially suffer specific forms of discrimination at the same time. ${ }^{1}$

Crenshaw and other scholars began criticizing the single ground approach for neither providing adequate protection nor a full picture of the phenomenon because, according their opinion, an analysis on a single issue of discrimination did not reflect reality. They also criticized how that analysis generally dealt with one ground of discrimination and not the combination or the addition of more grounds. For this reason, they found that the legislation did not properly address the type of discrimination suffered mainly by many AfricanAmerican women. ${ }^{2}$

The notion of multiple discrimination was further developed by a Finnish scholar, Timo Makkonen. ${ }^{3}$ According to him, the term "multiple discrimination" describes the first of three situations where a person can be subjected to discrimination on more than one ground. This kind of discrimination occurs when a person is discriminated by different factors (race, gender, etc.) in various times. It can be mentioned, for example, the case of a disabled woman who may be discriminated because of gender for the acquisition of a job position and her difficulty of entering a public building not accessible to people using wheelchair. The victim accumulated various experiences of discrimination which differentiate from the time of suffering and the factor that causes it. Makkonen argues that

* Research Fellow, Institute for International Legal Studies, National Reasearch Council (ISGICNR), Italy.

E-mail: silvana.moscatelli@uniroma1.it

${ }^{1}$ Crenshaw, K.: Demarginalizing the Intersection of Race and Sex: A Black Feminist Critique of Antidiscrimination Doctrine, Feminist Theory and Antiracist Politics. University of Chicago Legal Forum, 1989, 67-139. See also Crenshaw et al. (eds): Critical Race Theory. The Key Writings that Formed the Movement. New York, 1995.

2 Martinez, F. R.: La discriminación múltiple, una realidad antigua, un concepto nuevo. 4 et seq., http://www.oberaxe.es/files/datos/492a7ea083086/discriminacionmultiple.pdf.

${ }^{3}$ Makkonen, T.: Multiple, Compound and Intersectional Discrimination: Bringing the Experiences of the Most Marginalized to the Fore. Institute For Human Rights, Abo Akademi University, April, 2002, http://web.abo.fi/instut/imr/norfa/timo.pdf 
in these cases it is appropriate the use of adjective "multiple" because of its mathematical connotations: the victim is discriminated by factors acting simultaneously or jointly, but separately, as a sum: gender+disabilities. ${ }^{4}$ This concept of multiple discrimination does not coincide with that one of Crenshaw.

According to Makkonen, there are other form of discrimination. For instance, the term compound discrimination describes rather a situation where a person suffers discrimination on the basis of two or more grounds at the same time, and where one ground adds to discrimination on another ground. It particularly refers to a situation in which one or more discrimination factors are added to others in a specific case producing a barrier or adding an existing difficulty. ${ }^{5}$ For example, in a labour market that segregates on the basis of gender (some jobs are reserved to men) and nationality (some jobs are available only to nationals), the chances that a immigrant woman finds a job according to her education are considerably reduced. ${ }^{6}$

With reference to the different kind of discrimination, it is also to mention the intersectional discrimination. This refers to a situation in which various discriminatory factors interact simultaneously, producing a specific form of discrimination. For example, the discrimination of a gypsy woman is the result of the combination of gender and ethnicity, which differs from discrimination against non-gipsy women or gipsy men. ${ }^{7}$

The conceptual disorganization involved, as several different concepts, such as "multiple discrimination", "double/triple discrimination", "multidimensional discrimination", "intersectional discrimination" and "intersectional vulnerability" have been used to describe essentially similar or comparable situations. In the academic field, the concept of "intersectional discrimination" is favoured while references to "multiple discrimination" are scarce, while in the field of human rights the opposite is true. ${ }^{8}$

4 Ibid. 10.

5 Ibid. 11.

${ }^{6}$ An example of compound discrimination is case of Perera vs. Civil Service Commission, No. 2 (1983) in the UK. In Perera case an advertisement for a legal assistant stated that candidates with a good command of the English language, experience in the UK and with British nationality would be at an advantage. That puts a higher than average proportion of some racial groups at a disadvantage. Nevertheless, in Perera vs. The Civil Service Commission, the Court of Appeal held that an advertisement for a legal assistant that stated that candidates with a good command of the English language, experience in the UK and with British nationality would be at an advantage did not amount to a requirement or condition within the meaning of the Race Relations Act 1976, section 1(1)(b). To come within the Act the preference should be elevated to a requirement or "absolute bar" which has to be complied with.

7 The concept of intersectional discrimination is also known in the Canadian system. The Ontario Human Rights Commission in Canada has been active in promoting an understanding of multiple discrimination by incorporating an intersectional approach in their equality work. Apart from the need to develop the intersectional approach and other legal mechanisms to tackle multiple discrimination there is a need to identify substantive practice to prevent and combat multiple discrimination. On the basis of a study pursued by the Ontario Human Rights Commission, complaints filed between April 1997 and December 2000 indicate that 48\% of the complaints included more than one ground, while $52 \%$ cited only one ground of discrimination, $56 \%$ of age complaints included other grounds; $19 \%$ of complaints filed on the ground of handicap included multiple grounds; $27 \%$ of cases filed on the ground of sex included multiple grounds; $94 \%$ of complaints citing the ground of receipt of public assistance, including other grounds. http://www.ohrc.on.ca/en/resources/discussion consultation/DissIntersectionalityFtnts?page=DissIntersectionalityFtnts-OTHER.html.

8 Makkonen: op. cit. 8. 
In some branches of socio-legal research there has been a progressive acknowledgement of the role that multiple discrimination. However, the law has been slow to recognise and respond to the concept of multiple discrimination in practice and, consequently, there are few cases addressing discrimination on more than one ground. ${ }^{9}$ The ability of a legal system to adequately address cases where claimants have suffered discrimination on multiple grounds is vital if the law is to be able to prevent disadvantage and to compensate sufferers sufficiently. While law in the United States have shown a developing recognition of the issue of multiple discrimination, in many EU Member States, legislation does not dealt with the needs of victims experiencing multiple discrimination. ${ }^{10}$

\section{The international legal foundation of multiple discrimination}

The Universal Declaration of Human Rights (UDHR), adopted by the United Nations General Assembly on 10 November 1948, states the principle of equality and nondiscrimination. Even though the Declaration is a non-legally binding document it has been accepted as international customary law, whereas some articles, such as the nondiscrimination provision in Art. 2, have even acquired the status of jus cogens. ${ }^{11}$

The non-discrimination provision in Art. 2 of the UDHR reads that everyone is entitled to all the rights and freedoms set forth in the Declaration, without distinction of any kind, such as race, colour, sex, language, religion, political or other opinion, national or social origin, property, birth or other status. The article does not have independent standing, but is, in a way, accessory to the other articles of the Declaration. ${ }^{12}$

The principle of non-discrimination is also recognised by the International Covenant on Civil and Political Rights (ICCPR), under Art. 2 which affirms that each State Party to the Covenant undertakes to respect and to ensure to all individuals within its territory and subject to its jurisdiction the rights recognised in the Covenant, without distinction of any kind, such as race, colour, sex, language, religion, political or other opinion, national or social origin, property, birth or other status. ${ }^{13}$ The same provision is encompassed under Art. 2 of the Covenant on Economic, Social and Cultural Rights (ICESCR). ${ }^{14}$

Beyond the mentioned instruments, the principle of non-discrimination is also contained in the Convention on the Elimination of All Forms of Racial Discrimination (CERD) concluded in 1965 and the Convention on the Elimination of All Forms of Discrimination Against Women (CEDAW) adopted in 1979.

9 European Union Agency for Fundamental Rights, Multiple Discrimination, Data in Focus Report, EU-MIDIS, 2010, 6.

10 Britton, E.: Multiple Discrimination in the USA: A Growing Recognition of the Interlocking Nature of Disadvantage. http://www.suite101.com/content/multiple-discrimination-in-the-usa-a45059 \#ixzz1ORA3O2t.

11 On the Universal Declaration of Human Rights see, inter alia Morskin, J.: Universal Declaration of Human Rights: Origins, Drafting, and Intent. Philadelphia, 1999.

12 Makkonen, T.: The Principle of Non-discrimination in International Human Rights Law and EU Law. 5, http://iom.fi/elearning/files/national_law/estonia/essential_reading/Principle_of_Non_ Discrimination.pdf.

13 On the scope of application of Art. 2 ICCPR see Committe on Human Rights, General Comment No. 18, adopted on 10 November 1989.

14 On the ICESCR see inter alia Craven, M.: The International Covenant on Economic, Social and Cultural Rights. A Perspective on Its Development. Oxford, 1995. 
Nevertheless, in the above-mentioned instrument there is no reference to the notion of multiple discrimination. One of the first reference to multiple discrimination is encompassed in the Beijing Declaration and Platform for Action, which were adopted by the Fourth World Conference on Women in September 1995 explicitly address the specific situation and experience of e.g. disabled women, immigrant women, indigenous women and rural women, in addition to which intersectional issues such as trafficking and violation of the rights of women during armed conflicts are discussed. The Declaration uses the terms to "multiple barriers" and even though it does not clearly deal with multiple or intersectional discrimination, it is widely regarded that this was the first instance ever in which these issues were addressed on such a high level. ${ }^{15}$

At international level, the concept of multiple discrimination has been clearly recognised by the Durban Declaration adopted at the World Conference against Racism, Racial Discrimination, Xenophobia an Related Intolerance in 2001. The Declaration and the Programme of Action adopted at the Conference contain numerous explicit references to the concept of multiple discrimination, in addition to which some provisions deal with concrete issues such as women in armed conflicts, trafficking and the right of an indigenous or minority child to enjoy his or her own culture and practice his or her own religion.

Already the preamble to the Declaration emphasizes that states have a duty to protect and promote the human rights and fundamental freedoms of all victims of racism and racial discrimination, and that they should apply a gender perspective and recognise the multiple forms of discrimination which women can face. Under Art. 2, the Declaration specifically affirms that racism, racial discrimination, xenophobia and related intolerance occur on the grounds of race, colour, descent or national or ethnic origin and that victims can suffer multiple or aggravated forms of discrimination based on other related grounds such as sex, language, religion, political or other opinion, social origin, property, birth or other status. ${ }^{16}$

Although the list of related grounds is open-ended, some grounds are expressly included in the list of related grounds. ${ }^{17}$ The list of related grounds does not contain, most notably, disability, sexual orientation or age, which are all grounds that have been quite firmly recognised in international and EU law. ${ }^{18}$

The Programme of Action expressly recognises multiple discrimination by way of recognizing, inter alia, that people of African descent experience particularly severe problems of religious intolerance and prejudice that can combine with other forms of discrimination to constitute multiple discrimination (Art. 14), that multiple discrimination can take place in the context of employment, health care, housing, social services and education (Art. 49).

It is worth to underline that the Durban Conference and the documents adopted therein clearly evidence overwhelming international recognition of intersectional and multiple discrimination. As regards the field of human rights, the adoption of the Durban Declaration and Programme of Action in the UN World Conference against Racism in 2001 represented a major milestone in recognizing the way discrimination on the basis of origin and

15 Makkonen: The Principle of Non-discrimination ... op. cit. 3, 37.

16 Ibid. 3, 46.

17 Ibid.

18 Disability, sexual orientation and age have been recognised as explicitly forbidden grounds of discrimination, e.g. in the EU Council Directive 2000/78/EC prohibiting discrimination in employment 
respectively on the basis of sex/gender can interact and produce previously unrecognised forms and manifestations of discrimination. ${ }^{19}$

In the international context, it is also important to mention that the 2006 Convention of the United Nations on the Rights of People with Disabilities which recognises multiple discrimination. Already the Preamble of the Convention affirms that the State Parties are concerned about the difficult conditions faced by persons with disabilities who are subject to multiple or aggravated forms of discrimination on the basis of race, colour, sex, language, religion, political or other opinion, national, ethnic, indigenous or social origin, property, birth, age or other status. ${ }^{20}$ Under Art. 6, the Convention specifically affirms that women and girls with disabilities are subject to multiple discrimination, and in this regard State Parties shall take measures to ensure the full and equal enjoyment by them of all human rights and fundamental freedoms. Regarding to the Convention, it is worth to remind that it is a legally binding instrument and State parties have the duty to fulfil the obligations defined by the Convention. Thus, each State Party has to take measure in order to avoid multiple discrimination towards women and girls takes place. ${ }^{21}$

\section{The recognition of multiple discrimination in the European context}

At European level, the nationality and gender were the only equality issues on the legal agenda from the outset and for about 40 years. Prohibition of discrimination both on grounds of nationality and gender was originally introduced in EU law as a means to develop the internal market. In this discourse, multiple discrimination was practically not faced in official EU legal texts until the 1990s. Since 1999, the European Union has created a body of legislation aimed at combating discrimination on the grounds of ethnic and racial origin, religion and belief, sexual orientation, disability and age. ${ }^{22}$

With the incorporation of Art. 13 into the EC Treaty, entered into force in 1999, the adoption of the two anti-discrimination directives in 2000, the Community action programme to combat discrimination, ${ }^{23}$ PROGRESS and the 2007 European Year of Equal Opportunities for All, the EU and its Member States have experienced a dynamic development in antidiscrimination legislation and substantial initiatives to raise awareness of discrimination.

Whit this regard it is also to mention Art. 2 TEU which provides that the "Union is founded on the values of respect for human dignity, freedom, democracy, equality, the rule of law and respect for human rights, including the rights of persons belonging to minorities. These values are common to the member states in a society in which pluralism, nondiscrimination, tolerance, justice, solidarity and equality between women and men prevail".

19 Makkonen: The Principle of Non-discrimination ... op. cit. 3, 55.

${ }^{20}$ Hendriks, A.: The UN Disability Convention and (Multiple) Discrimination: Should EU Non-Discrimination Law Be Modelled Accordingly. European Yearbook of Disability Law, 2 (2010), $7-27$.

21 On this aspect see Della Fina, V.: Articolo 6, Donne con disabilità (Article 6, Women with disability). In Cera, R.-Della Fina, V.-Marchisio, S. (eds): La Convenzione delle Nazioni Unite sui diritti delle persone con disabilità (The UN Convention on the rights of people with disabilities Commentary). Roma, 2010, 105-118.

22 Nielsen, R.: EU Law and Multiple Discrimination. CBS Law Studies, WP 2006-01, 1.

23 Council Decision 2000/750/EC of 27 November 2000 establishing a Community action programme to combat discrimination (2001 to 2006). 
At the level of the European Union the mentioned principles are also enshrined in Art. 21 of the Charter of Fundamental Rights of the European Union. According to this article, any discrimination based on grounds such as sex, race, colour, ethnic or social origin, genetic features, language, religion or belief, political or any other opinion, membership of a national minority, property, birth, disability, age or sexual orientation shall be prohibited. Furthermore, Art. 19 TFEU gives the Union the competence to combat discrimination on grounds of sex, racial or ethnic origin, religion or belief, disability, age and sexual orientation.

With the addition of the new grounds of discrimination, such as race or ethnic origin, age, disability, religion or belief and sexual orientation, the concept of multiple discrimination has grown in importance.

As observed above, the adoption of some directives contributed to address discrimination across a range of grounds and in different contexts encompassing employment through to goods and services.

The Race Equality Directive (2000/43/EC), adopted in 2000, prohibits discrimination on the grounds of racial or ethnic origin, with a view to putting into effect in the Member States the principle of equal treatment. The scope of the Directive is very broad In the preamble to the Directive there is reference to the general human rights provisions. It applies to all persons, as regards both the public and private sectors, including public bodies, in relation to conditions for access to employment, to self-employment and to occupation and access to and supply of goods and services which are available to the public, including housing.

It is also important to mention the Employment Equality Directive (2000/78/EC) which establishes a framework for equal treatment in employment and occupation and in Art. 1 lays down a general framework for combating discrimination on the grounds of religion or belief, disability, age or sexual orientation as regards employment and occupation.

Finally, Gender Directive (2004/113/EC) which expands protection against gender discrimination to access to and the provision of goods and services.

Although the directives do not expressly provide for the consideration of multiple discrimination they do not prohibit, but expressly recognise that different grounds may intersect. Recital 14 of the Race Directive affirms that in implementing the principle of equal treatment irrespective of racial or ethnic origin, the Community should aim to eliminate inequalities, and to promote equality between men and women, especially since women are often the victims of multiple discrimination.

Following the passing of the Racial Equality Directive and the Framework Equality Employment Directive, the Council of the EU, launched a Community Action Programme to promote measures to combat direct or indirect discrimination based on racial or ethnic origin, religion or belief, disability, age or sexual orientation. In recital 4 to the Council decision it is stated, in accordance with the gender mainstreaming provision in Art. 3(2) EC (Art. 8 TFEU), that in the implementation of the programme, the Community will seek, in accordance with the Treaty, to eliminate inequalities and promote equality between men and women, particularly because women are often the victims of multiple discrimination. ${ }^{24}$

In recital 5 to the Decision establishing the Programme it is furthermore stated that the different forms of discrimination cannot be ranked because they are all equally intolerable. The programme is intended both to exchange existing good practice in the Member States

${ }^{24}$ Council Decision 2000/750/EC of 27 November 2000 establishing a Community action programme to combat discrimination (2001 to 2006). 
and to develop new practice and policy for combating discrimination) including multiple discrimination, promoting gender mainstreaming provision in accordance to Art. 3(2) EC (Art. 8 TFEU). ${ }^{25}$

In 2006, the European Commission required a study on multiple discrimination. It requested the European Network of Legal Experts in the Field of Gender Equality to provide a complementary report to cover 30 states, and to focus on legal problems related to gender equality and multiple discrimination. The mandate of this report was to highlight legal perspectives on discrimination against women based on grounds additional to their sex, and to make recommendations for further research or policy measures. ${ }^{26}$

Also the European Parliament has frequently highlighted the problem of multiple discrimination. In its resolution on the Stockholm Programme ${ }^{27}$, it stressed that while EU law and policy markers have adopted an extensive body of law to combat the multiple discrimination suffered by woman from minority backgrounds, especially Roma women, no significant progress can be demonstrated: it therefore called on the EU Member States "to review the implementation of all policies related to the phenomenon of multiple discrimination" 28 .

The importance of recognising multiple discrimination lies with the fact that it takes into account the complexity of discrimination as it is experienced by some people.

Some problems perceived in the field of multiple discrimination may not be due to the problems with this specific field but rather stem from implementation and divergences between national legal orders. ${ }^{29}$

\section{The Italian legal framework}

In Italy, the principle of non-discrimination is defined under Art. 3, Para. 2, of the Italian Constitution which recognises that "all citizens have equal social dignity and are equal before the law, without distinction of sex, race, language, religion, political opinion, personal and social conditions". For this reason, it is "the duty of the Republic to remove those obstacles of an economic or social nature which constrain the freedom and equality of citizens, thereby impeding the full development of the human person and the effective participation of all workers in the political, economic and social organisation of the country". ${ }^{30}$

25 Ibid.

${ }^{26}$ European Network of Legal Experts in the Field of Gender Equality: Multiple Discrimination in EU Law, Opportunities for Legal Reponses to Intersectional Gender Discrimination? 2009, 10.

27 The Stockholm Programme was adopted during the Swedish Presidency for the period 2010 2014. The Programme emphasises the ambition is to create a more secure and more open Europe, where the rights of the individual are protected and cooperation focuses on measures that provide added value for individuals. The Programme also gives great importance to how the EU should work to guarantee respect for fundamental freedoms and privacy, while guaranteeing security in Europe.

${ }^{28}$ European Parliament Resolution of 25 November 2009 on the Communication from the Commission to the European Parliament and the Council-An Era of Freedom, Security and Justice serving the Citizen-Stockholm Programme, Para. 31.

${ }_{29}$ Ashiagbor, D.: Multiple Discrimination in a Multicultural Europe: Achieving Labour Market Equality Through New Governance. Current Legal Problems, 61 (2008) 1, 265-288.

30 On the anti-discrimination law in Italy see Barbera, M. (ed.): Il nuovo diritto antidiscriminatorio. (The new anti-discriminatory law). Milano, 2007. For a comparative analysis with other countries see Schiek, D.-Waddington, L.- Bell, M. (eds): Non-discrimination Law. Oxford-Portland, 2007. 
The concept of multiple discrimination remained outside the framework of discrimination on the basis of race, ethnicity and nationality under Arts 43 and 44 of Consolidated Act 286/1998 on Immigration. Multiple discrimination only entered Italian legislation in the form of double discrimination. ${ }^{31}$ The only references to it are in legislative decrees Nos. 215 and 216 of 2003, transposing Directives 2000/43/EC and 2000/78/EC, and in the corresponding Delegation Act.

In particular, Art. 1 of Decree No. 215/2003 provides that the implementation of equal treatment irrespective of race and ethnic origin must take place "also in a perspective that takes into account the different impact that the same forms of discrimination can have on women and men, and the existence of forms of racism with a cultural and religious character". The implementation of Directive 2000/43/EC covered the legal vacuum of Italian legislation in the field of discrimination with reference to direct and indirect gender discrimination. ${ }^{32}$

Referring to the mentioned Decree, it is worth to remind that it fulfils the guideline provided by Delegation Act No. 39/2002, which in Art. 29 requires that the implementation of Directive 43/2000 take into account the existence of discrimination on the double ground of gender and race and ethnic origin.

A similar concept of multiple discrimination is provided by Art. 1 of Decree No. $216 / 2003$, which states that the implementation of equal treatment, irrespective of religion or belief, disability, age or sexual orientation, as regards employment and occupation must be carried out in "perspective that also takes into account the different impact that the same forms of discrimination can have on women and men". Multiple discrimination, therefore, is not properly defined and it is perceived by the legislator only as an intersection between the grounds of gender and other discriminatory factors. In this regard, some scholars made it clear that in this case, multiple discrimination does not represent a mere sum of factors, but rather factors that interact with each other, producing negative exponential effects". ${ }^{33}$

With regard to the case law, it is to notice that in Italy there is a group of cases in which gender discrimination could be recorded in combination with another ground of discrimination. These cases related to the pensionable age, which, in the Italian system, is lower for women than it is for men, although women can choose to keep working until the age provided for men. The criterion of reaching the age of retirement, irrespective of the lower pensionable age of women, is discriminatory both on the ground of gender and age. For this reason women can retire in younger age and earlier than man, despite the fact that women can choose to keep working until the retirement age provided for men. ${ }^{34}$

Despite the explicit recognition of a double combination of two risk factors, one of which is always represented by gender, in Italian case law some issue related to the double disadvantage were addressed regarding combination alien-disable. In 1998, the Constitutional Court extended to aliens lawfully residing in the Italian territory the form of "special protection of disadvantaged groups of citizens" (Sentenza n. 454 del 30.12.1998, in CC, 1998). In 2005, the Constitutional Court also declared unconstitutional the provision of the

31 Gottardi, D.: Le discriminazioni basate sulla razza e sull'origine etnica (Disriminations based on race and ethnic origin). In: Barbera, M. (ed.): Il nuovo ... op. cit. 1-42, at 24.

32 Gottardi, D.: Dalle discriminazioni di genere alle discriminazioni doppie e sovrapposte: le transizioni (From gender discrimination to double and overlapping discrimination: the transitions) Milano, 2003, 250.

33 Ibid. 251.

34 The European Network of Legal Experts in the Field of Gender Equality, note 24, at.77. 
regional law of Lombardy concerning local public transport in so far it did not include foreign residents among the persons entitled to free travel on public transport services reserved to totally disabled persons (Sentenza $n$. 432 del 2.12.2005, in CC, 2005). ${ }^{35}$

Nevertheless, the case law that deals with this issue, which is very limited, does not deal with the hypothesis of multiple discrimination. Thus, in Italian case law, there are no cases of multiple discrimination involving gender discrimination and one or more other grounds of discrimination. ${ }^{36}$

\section{Concluding remarks}

The legal protection against discrimination based on the different grounds varies from one EU country to another. Many states have not provided for any interpretation or definition of grounds, limiting themselves to including the various grounds in the national implementation legislation without paying attention to their meaning. The discrimination on some grounds (age, disability and sexual orientation) is less covered by national laws than other grounds. In fact, national legislation may prohibit discrimination for all the grounds but only in some areas of life.

A growing body of academic and community-based research shows that across the EU especially homosexuals face relevant discrimination in access to social protection, health care and services, education, housing, goods and services. In this respect, EU antidiscrimination law has not yet fully recognised and provided protection for multiple discrimination outside the employment field, except in relation to race and gender.

At European level, plans should be made for the introduction specific provisions to tackle multiple discrimination. The most important issue is finding a shared definition of multiple discrimination. ${ }^{37}$ Thus, an EU definition of multiple discrimination and a specific prohibition of it to be implemented by national legislation would be crucial to introduce into domestic legislation the protection against this form of discrimination. ${ }^{38}$ Furthermore, an EU definition would play an important role in creating a common understanding of the concept, as has happened before in relation to concepts contained in the Directives on discrimination. ${ }^{39}$

35 See Gottardi, D.: Le discriminazioni ... op. cit. note 28, at. 25.

36 As observed by Simonetta Renga, in The European Network of Legal Experts in the Field of Gender Equality, Multiple Discrimination in EU Law (see note 24), in Italy there are cases where the criterion of reaching retirement is regarded as discriminatory exclusively on grounds of age, the gender ground being ignored (Tribunale Milano 27/4/2005) and cases where the existence of gender discrimination is denied and the age ground is not taken into consideration at all either (Cassazione No. 9866/2007; Cassazione No. 20455/2006; Tribunale Genova 30/9/1997), 78.

37 See the European Network of Legal Experts in the Field of Gender Equality, note 24, 81.

38 Ibid.

39 Ibid. 